\title{
PENGEMBANGAN POTENSI PARIWISATA PANTAI PANDANSIMO KABUPATEN BANTUL
}

\author{
Oleh: \\ Siti Nurjanah dan Heru Pramono \\ Program Studi Pendidikan Geografi, FISE UNY
}

\begin{abstract}
Abstrak
Tujuan penelitian Penilitian ini bertujuan untuk mengkaji potensi, hambatan, dan upaya pengembangan pariwisata di Pantai Pandansimo atas dasar potensi fisik dan non fisik.

Kajian ini merupakan penelitian deskriptif. Populasi aspek fisik yaitu seluruh kawasan wisata Pantai Pandansimo, sedangkan aspek non fisik meliputi; masyarakat (80 responden), wisatawan (110 responden), dan pengelola objek wisata. Data aspek fisik diperoleh melalui observasi dan dokumentasi, sedangkan aspek non fisik melalui wawancara. Teknik pengambilan sampel yang digunakan adalah 1) Sampel sistematik untuk masyarakat (2) Incidental sampling untuk wisatawan (3) Purposive sampling untuk pengelola objek wisata. Teknik analisis data yang digunakan adalah analisis klasifikasi, tabel frekuensi, deskriptif, dan SWOT (Strength, Weakness, Opportunity, dan Threat).

Hasil penelitian menunjukkan bahwa secara fisik maupun non fisik Pantai Pandansimo memiliki potensi yang baik untuk dikembangkan menjadi daerah tujuan wisata dan perikanan. Hambatan pengembangan secara fisik maupun nonfisik antara lain bahaya erosi pantai, kurang memadai sarana prasarana pendukung pariwisata, kebersihan lingkungan, ketersediaan air, aksessibilitas, vegetasi kurang terawat dan rawan terhadap gempa bumi dan tsunami. Perlu dilakukan upaya pengembangan kepariwistaan yang lebih optimal dan terencana oleh semua pihak yang terlibat dalam pengelolaan objek wisata. Arahan pengembangkan pariwisata secara umum yaitu; 1) Penciptaan Pantai Pandansimo menjadi wilayah pariwisata dengan ciri khas Beneficial Tourism, realisasi rencana tata ruang yang lebih terukur dan sustainability, pendampingan terhadap pelaku usaha dan lembaga usaha secara intensif, terprogram, terpadu dan berkesinambungan serta melibatkan masyarakat secara aktif dan partisipatif. Diupayakan konservasi gumuk pasir dan vegetasi pantai serta optimalisasi sektor pendukung kegiatan pariwisata dalam hal perikanan dan kelautan, keragaman kegiatan wisatawan dan optimalisasi pembangunan desa wisata dengan basis kampung nelayan.
\end{abstract}

Kata kunci: Pandansimo, Pariwisata, Potensi, arahan. 


\section{Pendahuluan}

Pemanfaatan dan pengembangan potensi sumberdaya perairan menjadi paradigma baru bagi pembangunan yang harus segera diwujudkan secara optimal. Kebijaksanaan ini sangat didukung dengan adanya potensi sumber daya perairan, terutama laut yang sangat luas di seluruh wilayah Indonesia. Dalam rangka mengaktualisasikan kewenangan dan otonomi daerah dibidang pengelolaan wilayah pesisir sejauh 12 mil dari garis pantai, sebagaimana diatur dalam Undang-Undang Nomor 32 tahun 2004 tentang Pemerintahan Daerah serta dalam mengantisipasi perimbangan keuangan daerah dari hasil pemanfaatan sumber daya kelautan sesuai dengan Undang-undang Nomor 33 Tahun 2004 maka berbagai daerah yang memiliki wilayah pantai hendaknya dapat segera menindaklanjuti kebijaksanaan bidang kelautan ini.

Rencana Tata Ruang Kabupaten Bantul dengan Peraturan Daerah Nomor 4 tahun 2002 telah menetapkan adanya suatu Kawasan Pantai Selatan sebagai bagian dari pengembangan wilayah Kabupaten Bantul, sedangkan sesuai dengan Rencana Detail Tata Ruang Kawasan Pantai Selatan kabupaten Bantul yang telah dibuat dengan menetapkan adanya tiga sub kawasan pengembangan, yaitu Sub Kawasan I Parangtritis, Sub Kawasan II Samas, dan Sub Kawasan III Pandansimo.

Kabupaten Bantul memiliki wilayah pesisir sepanjang lebih kurang 20 km dan menjadi salah satu pusat wisata pantai dengan berbagai atraksi wisata dan keunikan yang ada serta kegiatan ekonomi yang bersifat homogen (perikanan tangkap) sehingga mendorong wisatawan berkunjung khususnya kawasan Pantai Pandansimo.

Pantai Pandansimo terletak kurang lebih 27 kilometer di Sebelah Selatan Kota Yogyakarta, berada di wilayah Desa Poncosari, Kecamatan Srandakan, Kabupaten Bantul, yang merupakan kampung nelayan di kawasan Pantai Pandansimo. Kawasan Pantai Pandansimo terkenal dengan Tempat Pelelangan Ikan (TPI) saat ini mengalami pertumbuhan, sehingga perlu ditata agar tidak lepas kendali. Pantai Pandansimo sebagai bagian dari kawasan pengembangan lebih dikhususkan pada kawasan wisata bahari khususnya dalam pengelolaan hasil laut. Lokasi ini merupakan kawasan dengan arahan fungsi perikanan yang menjadi sektor primer dan sebagai wisata ritual.

Wisatawan yang berkunjung di Pantai Pandansimo tidak banyak sehingga terkesan sepi pengunjung, dan kebanyakan hanya masyarakat lokal saja yang memanfaatkan lokasi ini. Hal ini membuktikan bahwa potensi yang ada di Pantai Pandansimo belum sepenuhnya dikenal oleh masyarakat luar daerah umumnya. Kegiatan para nelayan menjadi daya tarik bagi pengunjung Pantai Pandansimo meskipun jumlah pengunjung tidak banyak. Kegiatan para nelayan tersebut diantaranya nelayan bersama para pendorong menurunkan perahu ke laut maupun menarik perahu dari laut. Kegiatan nelayan ini dapat 
dikembangkan sebagai wisata bahari. Tetapi, pemandangan seperti ini tidak dapat dilihat oleh wisatawan pada saat ombak di Pantai Pandansimo dalam kondisi pasang naik sehingga nelayan tidak melakukan aktivitas melaut. Keberadaan jumlah pedagang ikan, nelayan yang cukup banyak jumlahnya memungkinkan adanya kemajuan yang pesat dalam bidang perikanan, dan diharapkan mampu menumbuhkan kawasan wisata yang berbasis kuliner. Terdapat sejumlah warung makan tradisional yang letaknya tidak jauh dari bibir pantai yang bergabung dengan rumah penduduk, menu yang disajikan hanya satu macam saja yaitu goreng. Tidak banyak wisatawan memanfaatkan jasa masak yang ditawarkan pada warung tersebut.

Aktivitas perikanan laut oleh masyarakat lokal di Pantai Pandansimo dimulai dari adanya bentuk inovasi dari nelayan pendatang, terutama nelayan dari Cilacap yang datang sekitar tahun 1997 di Pantai Depok yang kemudian merambah kegiatan perikanan tangkap di sepanjang wilayah pesisir termasuk di Pandansimo. Nelayan di Kabupaten Bantul mempunyai "Cilacap connection" yang kuat, yakni sebuah pertalian antar daerah yang saling membutuhkan. Nelayan pendatang membutuhkan "ladang ikan" baru yang potensinya masih besar, sedangkan warga di Pantai Pandansimo membutuhkan keahlian.

Kegiatan menangkap ikan dilakukan hampir sepanjang tahun. Di luar musim paceklik ikan yang berlangsung antara bulan Juni - September, jumlah hasil tangkapan cukup lumayan. Karena jumlah tangkapan cukup besar, sehingga ada inovasi baru untuk pembangunan sarana pemasaran hasil tangkap yang berupa warga TPI bernama Pandanmino. Pada awal berdirinya TPI di Pantai Pandansimo aktivitas nelayan dikatakan mencapai puncaknya antara tahun 1997-1998, dimana anggotanya terdiri dari dua Dusun yaitu Dusun Ngentak dan Dusun Kuwaru Desa Poncosari. Karena adanya dua kelompok atau dua dusun mereka merasa kesulitan terutama jaraknya cukup jauh dan adanya beberapa hambatan maka disepakati bahwa kelompok tani nelayan Pandansimo dijadikan dua, yaitu kelompok tani nelayan Pandanmino I yang bertempat di Dusun Ngentak dan kelompok tani nelayan Pandanmino II yang bertempat di Dusun Kuwaru.

Dalam kurun kegiatan perikanan tangkap kelompok nelayan ini menjadi juara ditingkat Kabupaten Bantul dalam kegiatan OPTIKAPI (Optimalisasi Penangkapan Ikan), dan OPTILANPI (Optimalisasi Tempat Pelelangan Ikan). Sarana dan prasarana pendukung di Pantai Pandansimo masih terbatas diantaranya belum terdapat penginapan, sarana angkutan umum hanya menjangkau Pantai Pandansimo belum menjangkau daerah perikanan tangkap di Dusun Kuwaru, kondisi jalan yang sempit dan kurang lancar dikarenakan sedang ada perbaikan jalan di dekat bantaran Sungai Progo, kurangnya kesadaran pengunjung dan masyarakat dalam menjaga kebersihan serta minimnya jumlah tempat pembuangan sampah yang menjadikan wilayah tersebut menjadi kesan sangat kumuh, tidak tersedia tempat untuk berteduh 
bagi para pengunjung, dan tidak tersedia sarana bermain anak serta vegetasi pantai yang kurang terawat.

Berkembangnya Pantai Pandansimo dengan potensinya sebagai wisata pantai, wisata perikanan tangkap dan wisata kuliner diharapkan dapat memberikan sumbangan ekonomi terhadap pemerintah daerah dan masyarakat. Namun, potensi yang dimiliki Pantai Pandansimo baik potensi fisik maupun non fisik belum dikembangkan secara optimal. Dalam kaitannya dengan usaha pengembangan, terdapat kendala yang menghambat pengembangan pariwisata di Pantai Pandansimo, baik dalam sarana, prasarana dan atraksi wisata serta kurang gencarnya upaya promosi. Berbagai upaya telah dan akan dilakukan oleh pengelola objek wisata dalam mengembangan kepariwisataan di Pantai Pandansimo baik terkait dengan Sumber Daya Manusia (SDM) maupun faktor penunjang lainnya.

Berdasarkan uraian tersebut, maka penulis tertarik mengadakan penelitian Pengembangan Potensi Pariwisata di Pantai Pandansimo Desa Poncosari Kecamatan Srandakan Kabupaten Bantul”.

\section{Pengembangan Pariwisata}

Pariwisata berasal dari bahasa sansekerta yaitu pari yang berarti banyak; berputar-putar; lengkap; dan wisata yang berarti perjalanan; berpergian. Jadi pariwisata adalah perjalanan yang dilakukan berkali-kali, dari suatu tempat ke tempat lain (Oka A. Yoeti, 1982 : 103). Menurut Kusmayadi dan Endar Sugiarto (2000: 4), pariwisata adalah suatu proses kegiatan melakukan perjalanan dari rumah menuju tempat lain dengan maksud tidak melakukan usaha atau hanya bersantai. Dorongan kepergiannya adalah karena berbagai kepentingan, baik kepentingan ekonomi, sosial, kebudayaan, politik, agama, kesehatan maupun kepentingan lain seperti sekedar ingin tahu, menambah pengalaman ataupun belajar dan bukan untuk melakukan kegiatan yang menghasilkan upah.

Alasan utama pengembangan pariwisata pada suatu daerah tujuan wisata, baik secara lokal, regional atau ruang lingkup suatu negara erat kaitannya dengan pembangunan ekonomi daerah atau negara tersebut. Alasan kedua pengembangan pariwisata itu lebih banyak bersifat non ekonomis. Wisatawan yang datang berkunjung pada suatu daerah tujuan wisata salah satu motivasinya adalah untuk menyaksikan dan melihat keindahan alam dan termasuk di dalamnya cagar alam, kebun raya, tempat bersejarah dan candicandi, bangunan-bangunan kuno, perkebunan dan sawah ladang. Alasan ketiga mengapa bidang pariwisata perlu dikembangkan ialah untuk menghilangkan kepicikan berpikir, mengurangi salah pengertian, terutama bagi masyarakat di obyek kepariwisataan itu dibangun (Oka A. Yoeti, 2008 : 77-78).

Tujuan lebih jauh dari pengembangan pariwisata adalah guna memperoleh nilai-nilai ekonomi positif dimana pariwisata diharapkan dapat 
berfungsi sebagai katalisator dalam pembangunan ekonomi pada beberapa sektor.

Menurut Sunarto (2001 : 8) wisata pantai ialah wisata yang objek dan daya tariknya bersumber dari potensi bentang laut maupun bentang darat pantai. Ditambahkan Sunarto (2001 : 8) wisata pantai dibedakan menjadi wisata pada bentang laut seperti berenang, memancing, bersampan, menyelam, berselancar, dan berperahu dan wisata pantai pada bentang darat seperti susur pantai, voli pantai, bersepeda, panjat tebing, menyusuri gua pantai dan rekreasi. Sementara Chafid Fandeli (2002 : 50), membaginya menjadi tiga macam kegiatan di areal pantai yaitu: Surface activities, Contact activities dan Litoral activities

Untuk menentukan kemungkinan pengembangan kepariwisataan di suatu wilayah perlu diketahui terlebih dahulu karakteristik kepariwisataan wilayah tersebut. Karakteristik tersebut dapat diidentifikasi melalui analisa SWOT (Strenghts, Weaknesses, Opportunities, and Threats), yang merupakan cara untuk mengenali karakteristik wilayah secara rinci dengan berbagai faktor tinjauan untuk dijadikan landasan bagi rencana pengembangan program sesuai dengan kondisi wilayahnya. Analisa SWOT terdiri dari dua hal yaitu faktor internal yang terdiri dari Strengths and Weaknesses dan faktor eksternal yang terdiri dari Opportunities and Threaths. Dalam analisa SWOT membandingkan antara eksternal peluang (Opportunities) dan ancaman (Threats) dengan faktor internal kekuatan (Strenghts) dan kelemahan (Weaknesses).

Pengembangan pariwisata pada dasarnya untuk memanfaatkan potensi yang dimiliki oleh suatu daerah, baik itu potensi fisik maupun potensi non fisik. Tujuan dari pengembangan tersebut adalah agar Daerah Tujuan Wisata (DTW) tersebut diminati dan banyak dikunjungi wisatawan. Wujud dari pengembangan pariwisata adalah pembangunan dan pengadaan sarana dan prasarana pariwisata.

Potensi fisik Pantai Pandansimo meliputi Potensi kondisi pantai, kondisi hidrologi, jenis penggunaan lahan, aksessibilitas, vegetasi pantai, sarana prasarana wisata dan keterkaitan dengan kegiatan wisata Pantai. Potensi non fisik antara lain meliputi tanggapan dan dukungan masyarakat, karakteristik dan dukungan wisatawan, jenis atraksi ekonomi, jenis atraksi budaya dan kegiatan promosi. Selain potensi fisik dan non fisik juga dilihat hambatan yang dihadapi dalam pengembangan pariwisata, yaitu terdiri dari hambatan fisik (kondisi pantai, kondisi hidrologi, jenis penggunaan lahan, aksesibilitas, vegetasi pantai, sarana prasarana wisata dan keterkaitan dengan kegiatan wisata Pantai Pandansimo) dan hambatan non fisik meliputi macam promosi dan jenis hambatan yang dihadapi oleh pelaku usaha.

Setelah diketahui potensi, hambatan dan upaya pengembangan oleh pengelola objek wisata di kawasan wisata Pantai Pandansimo, kemudian dianalisis menggunakan analisis SWOT dengan teknik skoring yang sudah 
dideskripsikan. Dari analisis tersebut kemudian didapatkan kemungkinan arahan pengembangan dari penulis yang bisa dilakukan dalam mengembangkan kepariwisataan di Pantai Pandansimo.

\section{Metode Penelitian}

Kajian ini termasuk penelitian deskriptif melalui pendekatan keruangan. Variabel penelitian ini yaitu potensi fisik dan potensi non fisik pengembangan pariwisata di Pantai Pandansimo. Potensi fisik meliputi kondisi pantai, kondisi hidrologi, penggunaan lahan, Aksessibilitas, keragaman jenis vegetasi peneduh, ketersediaan sarana dan prasarana pariwisata, dan keterkaitan dengan kegiatan kegiatan wisata pantai. Potensi non fisik meliputi tanggapan dan dukungan masyarakat, karakteristik wisatawan, segmentasi wisatawan.

Populasi dalam penelitian ini terdiri atas aspek fisik dan non fisik: Populasi fisik dalam penelitian ini adalah seluruh wilayah lahan Pantai Pandansimo termasuk didalamnya sarana, prasarana serta atraksi yang dimiliki. Populasi non fisik dalam penelitian yaitu seluruh Kepala Keluarga di sekitar kawasan wisata Pantai Pandansimo berjumlah 410 Kepala Keluarga, Wisatawan di Pantai Pandansimo yang diambil secara incidental, dan Pengelola objek wisata (Dinas Pariwisata Kabupaten Bantul, Dinas Peternakan, Kelautan dan Perikanan Kabupaten Bantul dan Koperasi Pandanmino I dan Pandanmino II).

Pengambilan sampel aspek non fisik untuk kepala keluarga menggunakan rumus dari Slovin ddiperoleh 80 Kepala keluarga. Sedangkan penentuan responden kepala keluarga $(K K)$ digunakan sampel sistematis (systematic sampling) sehingga diiperoleh sampel kelipatan lima. Pengambilan sampel wisatawan menggunakan "incidental sampling" dengan kuota hanya sejumlah 110 orang. Pengambilan sampel untuk pengelola objek wisata menggunakan teknik purposive sampling.

Teknik pengambilan data alat yang digunakan observasi, wawancara, dan dokumentasi. Teknik analisis data dilakukan melalui penyederhanaan, pemeriksaan (editing), tabulasi, dan Analisis Data secara deskriptif dan kuantitatif.

\section{Hasil Penelitian}

Kawasan Pantai Pandansimo menunjukan adanya karakteristik pantai berpasir. Kondisi kelengkungan garis pantai pada posisi melengkung lebih menyulitkan nelayan, dikarenakan terletak pada lokasi "lebeng/ bladon', yang cenderung dalam. Lokasi pendaratan perahu pasca tangkap dipengaruhi oleh fenomena pasang surut yang menyebabkan lebar zona pantai dan luasan daerah operasi pendaratan perahu mengalami fluktuasi. Kondisi tersebut dilatarbelakangi oleh material pantai yang berwujud material sedimen, yakni pasir dengan material halus. Pada selanjutnya terjadi proses sedimentasi 
sehingga menyebabkan zona Pantai Pandansimo menunjukan areal zona pantai yang sangat lebar, yang berdampak pada cukup luasnya areal operasi pendaratan perahu nelayan.

Daya tarik wisata yang dimiliki kawasan wisata berbasis alam meliputi pantai berpasir, keragaman vegetasi, dan gumuk pasir, daya tarik budaya berupa tempat-tempat peziarahan dan budaya lokal lainnya yang sering dilakukan oleh masyarakat sekitar. Sedangkan daya tarik wisata berbasis ekonomi meliputi aktivitas Tempat Pelelangan Ikan (TPI), aktivitas nelayan, dan warung makan sea food.

\section{Potensi Fisik Pantai Pandansimo}

Kondisi Pantai

Berdasarkan hasil observasi, keindahan panorama Pantai Pandansimo dikategorikan cukup beragam karena mempunyai empat keragaman panorama yaitu terdapat pasir di tepi pantai, tinggi ombak antara satu sampai dua meter, terdapat biota laut seperti jingking, undur-undur dan ikan, terdapat vegetasi pantai yang bagus di sebelah timur laut dan gumuk pasir di sebelah utara dan barat Pantai Pandansimo. Keindahan panorama Pantai Pandansimo ini termasuk kategori skor dua.

Kebersihan Pantai Pandansimo dipengaruhi oleh tiga faktor yaitu adanya permukiman, pengaruh sungai dan musim. Tingkat kebersihan di kawasan tempat wisata Pantai Pandansimo yang masih rendah terutama disebabkan oleh pengaruh gelombang dan ulah wisatawan yang tidak membuang sampah pada tempatnya. Sampah hasil dari Sungai Progo menjadi andil dalam penumpukan sampah di Pantai Pandansimo. Untuk aktivitas pelelangan ikan sejauh pengamatan tidak ada sampah yang berserakan dari hasil kegiatan perikanan, dikarenakan ikan hasil pelelangan langsung disortir oleh pedagang. Kebersihan pantai diberi skor dua.

Tipe gelombang di kawasan Pantai Pandansimo sulit mendorong wisatawan untuk melakukan kegiatan yang bersifat pasif seperti menikmati pemandangan lepas pantai, serta aktifitas aktif seperti memancing, bermain pasir, dan berolah raga seperti sepak bola, voly pantai, senam, dan kegiatan permainan kecil. Setiap hari Minggu Wage (hitungan jawa) kawasan pantai Pandansimo oleh masyarakat sekitar kabupaten Bantul dimanfaatkan untuk pengajian.

Ada kalanya untuk kegiatan pendidikan yang meliputi kegiatan perkemahan di sisi utara, studi ilmiahpun pernah dilakukan disini dalam rangka Praktek Kerja Lapangan oleh salah satu sekolah menengah atas jurusan kelautan yang ada di Kabupaten Bantul serta kegiatan jelajah alam susur pantai. Kondisi keragaman yang dilakukan wisatawan diberi skor tiga.

Keberadaan kanal galur, kegiatan pertanian lahan basah dan kering serta muara dari Sungai Progo memberikan suatu ciri khas yang berbeda 
dengan objek wisata pantai lainnya. Namun antraksi wisata yang ada masih belum cukup mengesankan sehingga dalam penilainnya diberi skor

Kondisi Hidrologi

Ketersediaan air bersih di kawasan wisata menjadi hal sangat penting untuk menunjang pelayanan yang maksimal bagi wisatawan. Hasil observasi ketersediaan air di tempat wisata Pantai Pandansimo terdapat sumber air bersih berupa sumur yang dibuat penduduk, jumlah sumur kurang dari tiga buah dan banyak sumur yang memang bukan dibuat dari pengelola objek wisata Pantai Pandansimo sehingga kelayakan untuk memperoleh air bersih bagi wisatawan rendah, selain itu karena kepemilikan sumur itu adalah masyarakat sekitar biasanya mereka memungut biaya yang banyak pada wisatawan.

Sarana air yang terdapat di dekat TPI sudah ada namun dilihat dari segi lokasi sumur atau sumber air tersebut kurang bisa dijangkau oleh wisatawan dan hanya wisatawan yang sengaja datang ke lokasi TPI yang dapat memanfaatkannya. Ada sumur yang disediakan oleh pengelola objek wisata namun keberdaannya sekarang sudah tidak layak selain dikarenakan pangaruh abrasi air laut, Gempa Bumi 27 Mei 2006, juga dikarenakan kurangnya perawatan oleh pengelola objek wisata. Kondisi ketersediaan air ini diberi skor dua termasuk kemudahan emperoleh air dan jarak sumber air terhadap lokasi objek wisata.

\section{Bentang lahan}

Penggunaan lahan sebagai daya tarik tempat wisata. Berdasarkan hasil observasi penggunaan lahan sebagai daya tarik wisata cukup beragam karena terdiri dari empat jenis yaitu permukiman, pertanian lahan basah, tegalan atau ladang, lahan kosong dan semak belukar atau jalur hijau, dan tambak udang serta perikanan oleh sebab itu diberi skor tiga.

\section{Aksesibilitas}

Berdasarkan data Monografi Desa Poncosari diketahui jarak tempat wisata Pantai Pandansimo dari Ibukota Kabupaten Bantul kurang lebih 16 kilometer. Wisatawan yang berkunjung ke Pantai Pandansimo yang menggunakan kendaraan pribadi tidak akan mengalami kesulitan untuk mencapai kawasan pantai ini, sedangkan wisatawan yang menggandalkan kendaraan umum akan mengalami kesulitan karena jumlah kendaraan umum yang melewati kawasan wisata ini hanya satu, sedangkan jika menuju TPI yang ada di Kuwaru harus dengan kendaraan pribadi. Jarak Pantai Pandansimo 2,6 kilometer dari ibukota kecamatan sedangkan jarak dari lbukota Kabupaten hanya $16 \mathrm{Km}$ sehingga diberi skor tiga sedangkan waktu tempuh menuju objek wisata dari ibukota kabupaten diberi skor dua. Prasarana jalan menuju objek dan ketersediaan sarana angkutan umum menuju objek diberi skor dua. 
Kondisi vegetasi Pantai Pandansimo

Berdasarkan hasil observasi diketahui terdapat beberapa jenis vegetasi yang khas seperti rumput grinting (spinifex littoreus), widuri (calotropis gigantea), pandan (pandanus), dan kaktus berbentuk entong (ipomea pescaprae). Selain vegetasi pantai terdapat juga tanaman budidaya seperti akasia, jarak, jambu mete, waru dan kelapa. Tanaman pertanian seperti tanaman palawija, lombok, ketela pohon, jagung dan bawang merah. Oleh sebab itu diberi skor tiga Ketersediaan Prasarana dan Sarana Wisata

Tempat wisata Pantai Pandansimo memiliki prasarana dan sarana wisata berupa warung makan untuk menikmati hidangan ikan laut, tempat parkir kendaraan tetapi saat ini masih bergabung dengan rumah penduduk. tempat ibadah, aula, WC umum, posko SAR sebagai salah satu jasa pelayanan bagi wisatawan, namun belum terdapat sarana penginapan ataupun hotel di kawasan ini. Apabila dilihat dari ketersediaan sarana dan prasarana wisatanya maka Pantai Pandansimo diberi skor dua.

Keterkaitan Dengan Kegiatan Wisata Pantai Pandansimo

Lokasi wisata Pantai Pandansimo menunjukan perkembangan objek wisata pantai yang didukung oleh perhatian dan arahan Pemerintah Kabupaten Bantul Propinsi Daerah Istimewa Yogyakarta. Perhatian tersebut diwujudkan dalam Peraturan Daerah (PERDA) retribusi Kabupaten Bantul No. 6 Tahun 2000, yang menunjukan aturan retribusi masuk objek wisata.adapun peraturan mengenai retribusi dikenakan sejumlah uang sebesar Rp. 1000,- / Fenomena yang ada juga menunjukan bahwa di Pantai Pandansimo ada aturan retribusi, sehingga dapat diasumsikan bahwa keterkaitan antara kegiatan wisata pantai dengan campur tangan pemerintah tinggi. .

Kegiatan wisata pantai juga ditunjukan dari keberadaan berbagai dagangan pendukung, seperti : jenis dagangan minuman, makanan, dan mainan sepanjang lokasi penelitian. Sebagian besar, berbagai jenis dagangan di lokasi adalah pedagang makanan dan minuman dan berada di kios-kios kecil yang sekaligus sebagai tempat tinggal penduduk setempat. Adanya kegiatan wisata pantai juga didukung dengan terdapatnya fasilitas terminal angkutan penumpang, tetapi keberadaannya harus di lakukan penataan ulang dikarenakan ada yang bergabung dengan permukiman penduduk. Oleh karena itu keterkaitan terhadap objek wisata diberi skor tiga

Hasil penelitian potensi fisik tempat wisata Pantai Pandansimo berdasarkan hasil observasi dapat diketahui bahwa jumlah skor keseluruhan dari potensi fisik tempat wisata Pantai Pandansimo adalah 35 yang berarti memiliki tingkat potensi Sedang. Klasifikasi tingkat potensi sedang berdasarkan penghitungan memiliki total skor antara 25,1-35. Berikut ini adalah tabel hasil penilaian potensi fisik tempat wisata Pantai Pandansimo. 


\section{Potensi Non Fisik Pantai Pandansimo}

Konsepsi pengembangan kawasan pesisir di Pantai Pandansimo harus dikembangkan dengan menerapkan sistem "tridaya" (Daya Manusia, Daya Lingkungan dan Daya Usaha), maka segala perencanaan dan keputusan harus dilakukan oleh masyarakat yang nantinya akan menjadi pemanfaat utama sekaligus bertanggung jawab dalam mempertahankan dan mengembangkan.

Kawasan pesisir Pantai Pandansimo dari keberadaannya sangat strategis jika dikaitkan dengan unit-unit satuan simpul pusat pengembangan kegiatan primer di wilayah pesisir pantai selatan yang ada secara menyeluruh terutama dibidang perikanan, pariwisata, budaya, perumahan dan permukiman serta fasilitas pendukungnya yang mempunyai dampak cukup signifikan. Karena terkait dengan daerah lain sehingga saling mengkait, terikat satu dengan lainnya dan saling membutuhkan baik secara sosial, ekonomi maupun kultural. Dengan cara penanganan tersebut, yaitu kawasan perencanaan diharapkan dapat membuka isolasi atau memperpendek jarak masyarakat dalam mengakses kemudahan yang berada di kawasan pesisir pantai.

Tanggapan Masyarakat dan Dukungan Masyarakat

Berdasarkan hasil kajian yang dilakukan tanggapan dan dukungan masyarakat terhadap pengembangan pariwisata yang mencakup 10 hal yaitu tentang: 1) penataan kembali kawasan Pantai, 2) pembentukan tempat rekreasi modern, 3) pembentukan tempat rekreasi bernuansa alam, 4) penataan dan penertiban Warung Makan Khas, 5) rencana pemindahan tpi ke arah timur, 6) penanaman pohon peneduh, 7) pembatasan kepadatan bangunan, 8) pembangunan gardu pandang, 9) penanganan Limbah, 10) dan pengadaan even Khusus, diperoleh hasil yang menunjukkan masyarakat mendukung atas upaya pengembangan pariwisata Pantai Pandansimo. Separuh lebih responden menyatakan setuju dan mendukung upaya menuju perbaikan kondisi kepariwisataan Pantai Pandansimo.

Karakteristik Wisatawan

Profil sosio demografi wisatawan berdasarkan jenis kelamin, kelompok umur, tingkat pendidikan, dan jenis pekerjaan diperoleh data sebagai berikut; jumlah wisatawan laki-laki yang berkunjung sebesar 50,9 persen dan jumlah pengunjung perempuan sebesar 49,1 persen. Kelompok umur 11 sampai 30 tahun sebesar (58 persen) paling banyak datang ke objek wisata. Latar belakang pendidikann sebagian besar wisatawan yaitu pendidikan menengah yaitu SMP dan SMA sebesar (34,54 persen), tidak sekolah (0,9 persen). Jenis pekerjaan wisatawan sebagian besar sebagai pelajar atau mahasiswa (45,5 persen), dan wiraswasta (26,4 persen).

Berdasarkan profil sosio psikografi wisatawan diperoleh rangkuman data sebagai berikut; 
Tabel. Profil sosiopsikografi wisatawan

\begin{tabular}{|c|l|l|c|}
\hline No. & Aspek Sosiopsikografi & \multicolumn{1}{|c|}{ Indikator aspek terbesar } & $\begin{array}{c}\text { Persentase } \\
\text { terbesar }\end{array}$ \\
\hline 1. & Alat transportasi & Pribadi (Sepeda motor dan Mobil) & 74,5 \\
\hline 2. & Pilihan Pola Perjalanan & $\begin{array}{l}\text { Berkelompok (keluarga, teman, } \\
\text { rombongan) }\end{array}$ & 89 \\
\hline 3. & Motivasi Kunjungan & Berlibur bersama keluarga & 51,9 \\
\hline 4. & $\begin{array}{l}\text { Alasan memilih } \\
\text { Pandansimo }\end{array}$ & Lokasi mudah dijangkau & 49,1 \\
\hline 5. & Banyak kunjungan & Lebih dari dua kali & 60,9 \\
\hline 6. & Lama kunjungan & Lebih dari dua jam & 63,6 \\
\hline 7 & Tanggapan kebersihan & Kotor & 72,8 \\
\hline 8 & $\begin{array}{l}\text { Tanggapan fasilitas yang } \\
\text { ada }\end{array}$ & Cukup -baik & 78,2 \\
\hline 9 & $\begin{array}{l}\text { Tanggapan kelengkapan } \\
\text { dan sarana prasarana }\end{array}$ & Kurang lengkap & 64,5 \\
\hline 10 & Kepuasan & Cukup puas & 60,9 \\
\hline 11 & Aktivitas wisata & Bersantai & 50 \\
\hline 12 & Pilihan hari kunjungan & Hari libur & 45,4 \\
\hline & & & 110 \\
\hline
\end{tabular}

Sumber: Data Primer, Maret 2009

Tabel menyajikan data bahwa segmentasi terbesar wisatawan yang berkunjung ke Pantai Pandansimo datang pada hari libur menggunakan kendaraan pribadi secara berkelompok dalam rangka liburan keluarga. Para wisatawan sebagian besar berlibur ke Pantai Pandansimo karena lokasinya yang mudah dijangkau dengan fasilitas cukup baik. Selain itu diperoleh data bahwa sebagian besar wisatawan berasal dari wilayah Kabupaten Bantul 63,6 persen disusul dengan wisatawan dari luar Kabupaten Bantul tetapi masih dalam Propinsi DIY 30 persen dan Propinsi lain sebesar 6,4 persen.

\section{Hambatan Pengembangkan Pariwisata Pantai Pandansimo}

Hambatan fisik yang terdapat di Pantai Pandansimo meliputi; bahaya erosi pantai tinggi, sarana prasarana pendukung pariwisata kurang memadai, kebersihan lingkungan yang kurang terjaga, ketersediaan air yang kurang mencukupi kebutuhan wisatawan, aksessibilitas yang kurang memadai, vegetasi kurang terawat dan rawan terhadap gempa bumi dan tsunami.

Kurang tersedianya sarana dan prasarana wisata berupa bangunan gardu pandang, penginapan, pusat informasi, biro perjalanan, tempat bermain anak-anak, panggung terbuka untuk festival kesenian seperti live music, tempat berteduh, kurangnya promosi yang dilakukan oleh pemerintah dan kesamaan produk dengan objek wisata yang dekat dengan Pantai Pandansimo. Sedangkan hambatan yang dihadapai pelaku usaha antara lain keterbatasan 
alat tangkap dan armada penangkapan ikan; pada musim paceklik (nelayan tidak bisa melaut karena faktor alam); proses penanganan dan pengolahan hasil perikanan tangkap oleh masyarakat, relatif kurang higienis dan belum ada diversifikasi produk; sarana perdagangan yang digunakan oleh para pedagang masih sangat sederhana. pengembangan objek wisata ini, belum dilaksanakan secara maksimal.

\section{Upaya Mengembangkan Kepariwisataan di Pantai Pandansimo.}

Upaya mengembangkan kepariwisataan di Pantai Pandansimo dilakukan oleh berbagai pihak seperti Koperasi Wisata yang menyediakan fasilitas sarana penunjang antara lain sarana parker dan warung. Pemerintaha memberikan bantuan sarana kenelayanan bagi nelayan di Pantai Pandansimo dan pelatihan bagi pengusaha rumah makan serta merencanakan menyediakan fasilitas pendukung seperti jalan, air bersih, penampungan limbah, penyediaan fasilitas keselamatan, penanaman pohon perindang, pembangunan dukungan perintisan proyek sarana usaha, pembinaan usaha, dan peningkatan Sumber Daya Manusia (SDM) pelaku usaha.

Masyarakat sekitar objek wisata pantai pandansimo juga melakukan upaya pengembangan wisata seperti terlibat sebagai aktor dalam pembangunan.

\section{Arahan Pengembangan Kepariwisataan di Pantai Pandansimo Dimasa Yang Akan Datang.}

Arahan pengembangan kepariwisataan di Pantai Pandansimo Kabupaten Bantul menggunakan analisis SWOT sebagai berikut:

1. Tata ruang kawasan di Pantai Pandansimo perlu disusun atau direalisasikan dalam bentuk Peraturan daerah.

2. Sarana prasarana penunjang kegiatan perikanan dan pariwisata yang sudah ada perlu ditingkatkan dan yang belum tersedia perlu segera dibangun.

3. Pendampingan terhadap pelaku usaha dan lembaga usaha wisata secara berkesinambungan.

4. Koperasi sebagai wadah induk dan koordinator semua lembaga yang ada

5. Upaya-upaya konservasi perlu ditingkatkan lagi

6. Penataan Tempat Pelelangan Ikan yang lebih baik sesuai karakteristik TPI

7. Konservasi Gumuk Pasir, sebagai atraksi wisata alam

8. Optimalisasi Sektor Perikanan dan Kelautan

9. Penertiban kawasan Permukiman

10. Merealisasikan rencana upaya pengembangan dari pemerintah. 


\section{Kesimpulan}

hasil penelitian dapat disimpulkan sebagai berikut:

1. Pantai Pandansimo ditinjau secara fisik memiliki potensi yang baik untuk dikembangkan menjadi daerah tujuan wisata dan perikanan. Disamping itu secara non fisik ada dukungan dari berbagia pihak seperti masyarakat sekitar, pemerintah, dan wisatawan yang sudah ke objek wsiata.

2. Hambatan secara fisik dari pengembangan Pantai Pandansimo menjadi kawasan wisata yaitu bahaya erosi pantai tinggi, sarana prasarana pendukung pariwisata kurang memadai, kebersihan lingkungan yang kurang terjaga, ketersediaan air yang kurang mencukupi kebutuhan wisatawan, aksessibilitas yang kurang memadai, vegetasi kurang terawat dan rawan terhadap gempa bumi dan tsunami. Sedangkan secara non fisik diperoleh hambatan yaitu masih kurang atau belum tersedianya sarana dan prasarana wisata

3. Perlu dilakukan upaya pengembangan kepariwistaan yang lebih optimal dan terncanan oleh semua yang terlibat terutama pengelola objek wisata dalam rangka mengembangkan kepariwisataan di Pantai Pandansimo

4. Arahan pengembangkan pariwisata secara umum yaitu;

a. Penciptaan lingkungan Pantai Pandansimo menjadi wilayah pariwisata dengan ciri khas Beneficial Tourism (pariwisata yang menghadirkan rejeki).

b. Realisasi rencana tata ruang yang lebih terukur dan sustainability

c. Pendampingan terhadap pelaku usaha dan lembaga usaha secara intensif, terprogram, terpadu dan berkesinambungan serta melibatkan masyarakat secara aktif dan partisipatif.

d. Diupayakan konservasi gumuk pasir dan vegetasi pantai

e. Optimalisasi sektor pendukung kegiatan pariwisata yaitu dalam hal perikanan dan kelautan, keragaman kegiatan wisatawan dan optimalisasi pembangunan desa wisata dengan basis kampung nelayan.

\section{Daftar Pustaka}

Bappeda Bantul. (2003). Rencana Induk Pengembangan Pariwisata Daerah Kabupaten Bantul. Yogyakarta: Puspar Universitas Gajah Mada.

Chafid Fandeli. (2001). Dasar-Dasar Manajemen Kepariwisataan Alam. Yogyakarta: Lembaga Penelitian, Pendidikan dan Penerangan Ekonomi dan Sosial (LP3ES).

Dinas Pariwisata. (2008). Tuorism Map Bantul Of Regency. Yogyakarta : Dinas pariwisata. 
Freddy Rangkuti. (1999). Analisis SWOT Teknik Membedah Kasus Bisnis. Jakarta: Gramedia Pustaka Utama.

Gamal Suwantoro. (1997). Dasar-Dasar Pariwisata. Yogyakarta: Andi Offset.

Kusmayadi dan Sugiarto, E.2000. Metodologi Penelitian Dalam Bidang Kepariwisataan. Jakarta: Gramedia Pustaka Utama.

Oka A Yoeti. 1982.Pengantar Ilmu Pariwisata. Jakarta: Pradnya Paramita.

1993. Perencanaan dan Pengembangan Pariwisata. Jakarta: Pradnya Paramita.

2008. Perencanaan dan Pengembangan Pariwisata. Jakarta: Pradnya Paramita.

Sujali. 1993. Geografi Pariwisata dan Kepariwisataan. Yogyakarta: Gadjah Mada University.

Sunarto. 2001. Geomorfologi Kepesisiran dan Peranannya Dalam Pembangunan Nasional Indonesia. Yogyakarta: Fakultas Geografi UGM.

Spillane, J.J. 1985. Ilmu Pariwisata Sebagai Pengantar Perdana. Jakarta: Pradnya Paramita. 